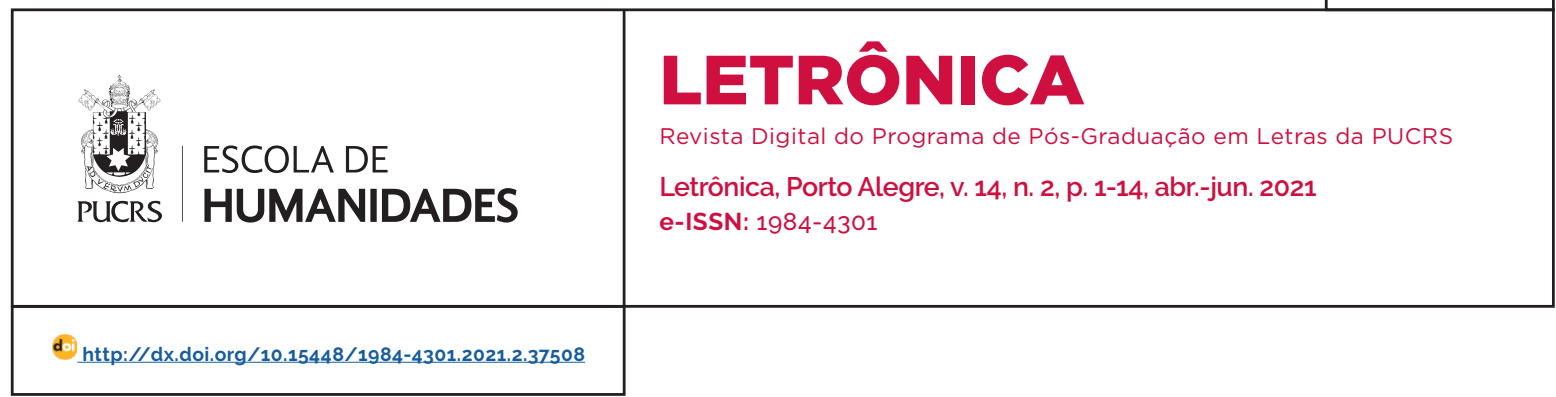

SEÇÃO: ARTIGOS

\title{
Using Tasks as a Pre-reading Procedure to Enhance L2 Reading Comprehension of Narrative Texts
}

\author{
Usando Tarefas como um Procedimento de Pré-leitura para Melhorar a Compreensão \\ Leitora de Textos Narrativos em L2
}

\section{Dionatan Bastos \\ Cardozo ${ }^{1}$}

orcid.org/0000-0001-6486-8448

cardozo.dionatan@icloud.com

\section{Lêda Maria Braga \\ Tomitch ${ }^{1}$ \\ orcid.org/0000-0003-4183-8072 \\ ledaacce.ufsc.br}

Received on: Aug. $07^{\text {th }}, 2020$ Accepted on: Aug. $15^{\text {th }}, 2020$

\section{(c) (1)}

Artigo está licenciado sob forma de uma licença Creative Commons Atribuicão 4.0 Internacional.
Abstract: Based on the assumption that preparing the reader before reading can foster reading comprehension, this research presents an empirical study in which the effects of pre-reading tasks on reading comprehension of narrative texts in English as a second language ${ }^{2}$ (L2) were investigated. Nine participants from a public high school took part in this investigation and to collect data, two Reading Comprehension Tests were fulfilled by participants right after reading each text. As stimuli, two narrative texts were selected. In the treatment condition, participants were exposed to the pre-reading tasks proposed by Willis and Willis (2011), which were adapted to fit the context of this research, prior to reading one of the narrative texts. In the control condition, the second text received a glossary at the end of the passage. The results provided evidence that pre-reading tasks are able to foster the reading comprehension of narrative texts in L2, since participants' performance was higher in the treatment condition, endorsing previous research on reading. Furthermore, the results also go in line with Willis and Willis' claim that pre-reading tasks are beneficial for reading comprehension of narrative texts. Keywords: Reading comprehension. Tasks. Second language. Pre-reading.

Resumo: Com base em pressupostos de que preparar o leitor para ler pode promover a compreensão leitora, esta pesquisa apresenta um estudo empírico no qual foram investigados os efeitos de tarefas de pré-leitura na compreensão de textos narrativos em segunda língua (L2). Nove estudantes de uma escola pública participaram da investigação e, para coletar dados, dois testes de compreensão leitora foram realizados pelos participantes logo após a leitura de cada texto. Como estimulo, dois textos foram selecionados. Na condição de tratamento, os participantes foram expostos às tarefas de pré-leitura propostas por Willis e Willis (2011), adaptadas ao contexto dessa pesquisa, antes da leitura de um texto narrativo. Na condição de controle, o outro texto recebeu um glossário no final da passagem. Os resultados evidenciaram que as tarefas de pré-leitura são capazes de promover a compreensão leitora de textos narrativos em L2. Esse resultado foi alcançado, uma vez que o desempenho individual de cada participante foi maior na condição de tratamento, endossando pesquisas anteriores sobre leitura. Além disso, essa pesquisa vai ao encontro da afirmação de Willis e Willis de que as tarefas de pré-leitura são benéficas para a compreensão da leitura de textos narrativos.

Palavras-chave: Compreensão leitora. Tarefas. Segunda língua. Pré-leitura.

\section{Introduction}

Reading is not a passive process. In fact, it is considered by many reading researchers as an interactive task (CARRELL, 1998; RUMELHART, 1977; GOODMAN, 1967, among others). This statement implies that a text is not fully finished by the writer, and as long as the reader is able to activate prior schemata and the text offers relevant information for reading, 
$\mathrm{s} /$ he can interact with the text by providing the necessary inferences and constructing meaning.

Considering interaction as a key concept for reading, some researchers have been investigating the use of pre-reading activities in order to inform reading comprehension instruction. Prior investigations have shown that preparing the reader before reading can help readers to better comprehend the text, reducing individual differences and fostering inferential processes, allowing the reader to interact with the text more efficiently when compared with only reading a text without any previous preparation (TAGLIEBER, 1985; TOMITCH, 1988; CALDART, 2012; ROSCIOLI, 2017).

Based on the previous research abovementioned, this article presents the results from an experiment in which the use of prereading tasks as a pre-reading procedure was investigated. The main objective of this study was to verify if reading comprehension is fostered when readers are prepared for reading a narrative text in English as a second language (L2), by adopting pre-reading tasks with the support of the Task-Based Language Teaching (TBLT) approach. To reach this objective, the following research question $(R Q)$ was proposed: What are the effects of pre-reading tasks (treatment condition), as compared to a glossary (control condition), on the reading comprehension of narrative EFL texts, as measured by comprehension questions?

To provide theoretical support for the study, a TBLT perspective towards the pre-reading procedures was adopted. In this respect, a set of tasks was adapted from Willis and Willis (2011) and used in the treatment condition of this investigation. According to the authors, a task consists of a set of activities that focus on language use in a communicative and effective way. Basically, the target language is used with a focus on meaning instead of on the linguistic form.

Based on Xavier (2012), the term 'activities' is used as an umbrella which embraces both 'tasks' and 'exercises'. Most of the time, researchers use both terms tasks and activities interchangeably. On the one hand, activities may have a focus on language meanings and, therefore, have an outcome, characterizing a task. On the other hand, activities may also include exercises that are, in fact, form-oriented activities done by the language learner with the sole purpose of practicing a grammatical topic (XAVIER, 2012). For this reason, in the present study we opted to use the term 'tasks' to refer to the dynamic pre-reading activities used here with a focus on language in use.

Altogether, the present study attempts to contribute to research in the area of reading as it offers a TBLT perspective to pre-reading activities, which are presented to readers before they approach narrative texts. In addition, it offers empirical evidence of a study conducted in a Brazilian public high school context, proposing a TBLT prism for schoolteachers to deal with $L 2$ texts inside the classroom.

\section{Review of the literature}

\subsection{The reading process}

In order to understand a text, the reader needs to have conceptual knowledge about the letters, phonemes, morphemes, words, ideas, schema, and topics, and also procedural knowledge in relation to decoding, literal comprehension and inferential comprehension, so that, meaning can be constructed from the interaction with the written passage (GAGNÉ et al., 1993; TOMITCH, 2011).

Therefore, for the act of reading comprehension to be accomplished by the reader, an array of cognitive processes has to be activated and performed during this process. There are three major processing models described in the literature that try to account for the reading process, from lower levels to higher levels of processing: the bottom-up model, the top-down model, and the interactive model.

The first model, bottom-up, was initially proposed by Gough in 1972. In this view, reading starts from an eye fixation on the page, involving fast successive events that begin when the reader encounters the visual input on the written page formed by letters. Based on this model, reading starts from the lowest level, in which the reader has to crack the code from the minimal visual 
stimuli, moving linearly from letters to words, from words to sentences and from sentences to meaning, in this sequential manner. Low proficient $L 2$ readers and young readers who are learning how to read in their first language (L1), often rely on bottom-up processing due to lack of appropriate linguistic knowledge. In addition, every reader may find him or herself in a situation where, due to the fact that they do not possess enough background knowledge in relation to the topics being discussed, they tend to stay at the surface of the text and read in a bottom-up way.

The second model is the top-down model, proposed by Goodman in 1967. For Goodman, reading is a selective process in which the reader brings his/her background knowledge and combine it with minimal language cues available on the written page in order to construct meaning from the information in the text. As reading goes on, the reader processes this partial information, deciding if the information provided by the text is useful to confirm predictions, reject or refine those predictions as $\mathrm{s} /$ he continues reading. As advocated by Goodman (1967), in a manner, the reader does not necessarily have to read the whole word to be able to infer meaning from it, but $\mathrm{s} /$ he can 'guess' the word just by using the context of the sentence or even with a small set of letters in the word as cues. Differently from reading in a bottom-up way, reading in a top-down fashion is not sequential, not even linear, but the reader is seen to move back and forth while reading, in a search for meaning, using minimal cues picked up from textual input in order to make up hypotheses that are checked against the text as reading progresses.

The third and last model to be reviewed here is the interactive model proposed by Rumelhart in 1977. In a nutshell, this reading model acknowledges that, in proficient reading situations, both processes, bottom-up and topdown, take place simultaneously, in parallel. Depending on the readers' background knowledge, proficiency and text type, bottomup or top-down processing will stand out as having a controlling role in the reading process
(AEBERSOLD; FIELD, 1997). According to this model, there is not a predetermined direction, but the reader is seen to be able to select among sources of information available including visual, orthographical, lexical, semantic, syntactic, and schematic information in order to comprehend the text (DAVIES 1995).

In essence, each individual processing model cannot stand alone to account for the whole complex process that reading stands for (DAVIES, 1995; BAILER, 2011) and cannot account for all reading situations. In this regard, the study here conducted finds support in all of the abovementioned models, since L2 reading depends on readers' prior schemata, language proficiency, reading proficiency, and other individual differences, all of which can influence the reading process and shape how comprehension is (or is not) achieved.

\subsection{Narrative texts}

As mentioned in the introduction of this article, the text type chosen to be part of the experiment reported here was the narrative type. According to Grabe (2009), a narrative text embraces narrative settings and thick descriptions of places and situations encircling episodic information. A reader when challenged to read this text type expects character development, episodes following a timeline of events, therefore, generating inferences to possible interpretations (LONG; JOHNS; MORRIS, 2006; OAKHIL; CAIN, 2006; PEARSON; FIELDING, 1991; ZWAAN; RAAP, 2006; GRABE, 2009). The awareness of episode sequences, motives, characters, and settings is what identifies the structure of a narrative.

Research so far has shown that narrative texts are easier to be understood, especially in L1 reading environments (FREEDLE; HALE, 1979; GRAESSER, 1981; GRAESSER; RIHA, 1984; SPIRO; TAYLOR, 1987; STEIN; GLENN, 1979; DUBRAVAC; DALLE, 2002). Scores on recall protocols are substantially higher indicating that this text type is easier to be understood and the time spent in reading it is shorter (DUBRAVAC; DALLE, 2002). According to Stein and Glenn (1979), this is due 
to the fact that the structure of a narrative text is acquired before schooling. In this regard, our everyday life is constructed as a narrative with a chronological sequence that follows a storyline.

However, when $L 2$ readers are challenged to read this text type, they often encounter some difficulties. According to Bensoussan (1990), L2 readers may face issues related to specific cultural differences, for example, they may lack background knowledge concerning the culture of the foreign language Besides, readers may face problems of global comprehension and, also, difficulties related to textual nuances such as ironies and metaphors, in which an L2 reader may not be able to identify the implicit meaning appropriately (DUBRAVAC; DALLE, 2002). Such problems may take the reader to stay at the surface of the written text (TOMITCH, 2009) and not be able to provide the necessary inferences in order to link textual information and thus achieve comprehension. The main hypothesis in the present study is that the pre-reading tasks used here will minimize possible difficulties $L 2$ readers may encounterwhile reading the narrative text presented.

\subsection{Pre-reading activities and tasks}

As a way to facilitate the reading process, and minimize the difficulties mentioned in the previous subsection, scholars have been defending the use of pre-reading activities as a way to activate existent prior knowledge, or to provide relevant knowledge, in case it is not part of readers' repertoire, in order to foster reading comprehension (LANGER, 1980; TIERNEY; CUNNINGHAM, 1980; TAGLIEBER, 1985; TOMITCH, 1991; CARRELL, 2006; ALEMI; EBALDI, 2010; BILOKCUOGLU, 2011, among others).

The main premise in pre-reading studies is that preparing the reader before they encounter the written passage promotes interaction with the text, hence, improving comprehension. In this regard, Tierney and Cunningham (1980) claim that by using pre-reading activities, we are able to guide readers during textual reading, facilitating comprehension. According to Langer (1980), pre-reading activities allow the reader to make connections between prior knowledge and content that will be encountered in the text, establishing a relation between them. In a research conducted by Tomitch (1991), participants were exposed to pre-reading activities and the results showed that they fostered reading comprehension by activating prior schemata. The research in the area shows that activating or building the reader's background knowledge before reading will improve reading comprehension and recall (TIERNEY; CUNNINGHAM, 1980). In a nutshell, prereading activities are able to activate and bridge readers' prior knowledge about the content of the text or, as mentioned before, to even provide the necessary background knowledge in order to foment textual comprehension.

Although there is a solid field of studies on pre-reading activities and its efficiency in reading comprehension, few investigations have been conducting experiments using the TBLT approach to pre-reading procedures. As a way to fulfill this gap, the present study brings tasks as an alternative to deal with pre-reading situations inside a classroom.

According to Ellis (2003; 2009), a task should primarily focus on meaning, taking learners to situations in which semantic and pragmatic meaning would be negotiated among peers. In a sense, this process should have some gaps to be fulfilled by students and these gaps should allow learners to express their opinions about a subject, relying on their linguistic resources, aiming for a language outcome.

For Nunan (2004, p. 4), a task is:

a piece of classroom work which involves lear-
ners in comprehending, manipulating, produ-
cing, or interacting in the target language while
their attention is focused on mobilizing their
grammatical knowledge to express meaning,
and in which the intention is to convey meaning
rather than to manipulate form.

To Willis (2008), the task will be configured as one if there is an opportunity to use meaningfocused language use, allowing learners to express themselves with language in their oral or written form.

Considering what is common in the definitions provided by the abovementioned authors, and in agreement with Willis, this study considers 
that a task consists of a cycle of activities that focus primarily on meaning. A task aims to allow students to use their linguistic resources to communicate, engaging in metacognitive processes granting the opportunity to establish a relation between what is learned and real life. For this matter, the set of tasks that nurtured the present study is brought in detail in the method section of this paper.

\section{Method}

\subsection{Context and participants}

This study was conducted at Colégio de Aplicação (CA) that it is part of Universidade Federal de Santa Catarina (UFSC), located in Florianópolis/SC/Brazil. The researcher had contact with all groups from the third year of High School, and, initially, twenty-seven participants agreed to participate in the study. Unfortunately, due to the timing of data collection, which occurred in the middle of a big students' strike at the University, only 9 students participated in all sessions of data collection and, thus, only their data are reported here.

The research had a within-subject design, and participants underwent both treatment and control conditions. The age of these participants ranged from 17 to 20, with a mean of 18,11 years old, being five girls and four boys. All participants were formally enrolled at CA and opted to have English classes in their foreign language curriculum. In addition, all participants were students from the last year of high school.

In accordance with Resolutions 466/12 and $510 / 16$ from the Brazilian Ministry of Health, the research proposal was submitted to the Ethics Review Board of the university (Comitê de Ética em Pesquisas com Seres Humanos da Universidade Federal de Santa Catarina - CEPSH-UFSC) and approved under the number 11735119.6.0000.0121 without any further recommendations.

\subsection{Instruments}

\subsubsection{Stimuli}

In order to account for the objective of this research, two narrative texts were selected: text A "The broken mirror" and text B "Alberto's new neighbors". Both texts were written in English and leveled as B1 (intermediate level) in the British Council website ${ }^{3}$, from where the texts were selected. The number of words in each of the texts was reduced in order to keep a balance between them and also to make them feasible for high school participants to read during the data collection sections, which should last about one and a half hour, each.

Stimuli 1 used in the treatment condition: narrative text A - "The broken mirror4".

Stimuli 2 used in the control condition: narrative text B with a glossary - "Alberto's new neighbors ${ }^{5}$ ".

\subsubsection{Pre-reading tasks}

As previously mentioned, text A was preceded by the pre-reading tasks that were adapted by the researcher with the support of the pre-task for a reading task as proposed by Willis and Willis (2011), based on the TBLT literature. In order to make the task more challenging and allow learning experiences, some of the pre-reading tasks proposed by Willis and Willis (2011) were adapted and will be presented in detail in this subsection.

The first task during the pre-reading moment is called Priming for Prediction (WILLIS; WILLIS, 2011). In this task, an image related to the text is presented alongside with the heading of the written passage. The picture presented was available at the British Council website with the text. The illustration was displayed on the projector and can be seen below:

\footnotetext{
Original text available at https://learnenglish.britishcouncil.org

Original text available at https://learnenglish.britishcouncil.org/general-english/stories/the-broken-mirror-the-black-cat-and-lots-of-good-luck.

Original text available at https://learnenglish.britishcouncil.org/general-english/stories/albertos-new-neighbours.
} 
Figure 1 - The broken mirror

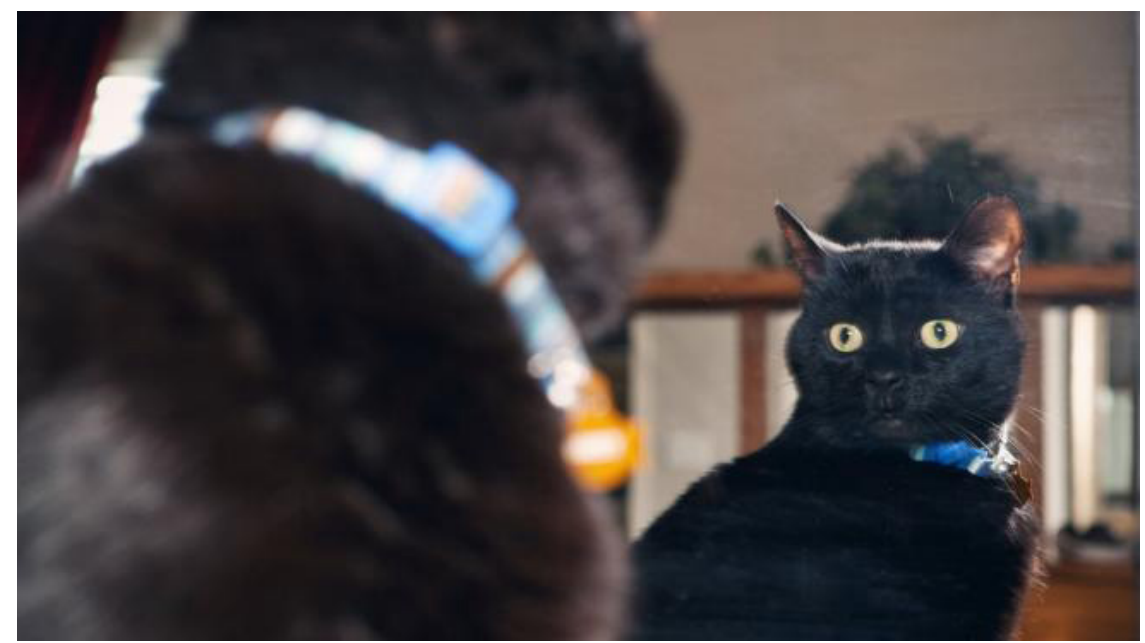

Source: British Council website

From the image above, the following questions were asked orally to participants, in English:

1. What do you see in this image?

2. What is happening in this image?

3. What is the possible relation between this image and the text that we are going to read?

Based on Willis and Willis (2011), this task involves meaning-focused language use, requiring students to use their linguistic resources to activate words related to the image and the heading of the text. These proposed questions were not part of the priming for prediction task proposed by Willis and Willis, but they were added in order to join the next step, which is the prediction task. By asking these questions, we thought that the possible keywords would be generated by the students and thus allow them to start to establish relations between the image and the content of the text from the beginning of the activity.

The second pre-reading task presented to participants was the Prediction Task (WILLIS; WILLIS, 2011). During this task, the teacher is expected to bring keywords and key sentences to help students. Initially, another adaptation had been made to the framework, and, in a pilot study, participants were asked to come up with the keywords that they thought were related to the text topic based on the image, and only then the researcher brought key sentences to be discussed. Unfortunately, the procedure proved to be disruptive, since participants would start to infer the possible topic of the text in advance, but in some cases, they would go over a totally different story that, in fact, obscured the real topic of the text. Based on that, a decision was taken to select five key sentences that opened the first five paragraphs in the text and they were displayed on the overhead projector by the researcher in the same order they appeared in the text. The sentences were read out loud, and the researcher told participants that these sentences were connected to the text. After that, participants were invited to sit in pairs or trios and were instructed to discuss about possible hypotheses towards the text topic, considering the key sentences presented from the text, the image, and keywords generated from the previous tasks and written on the board. Participants were given about five minutes to discuss with peers and take notes freely.

The third pre-reading task presented to participants was Preparing to Report. In this task, one student from each pair or trio was selected to report the ideas exchanged between them and the hypotheses created so far, based on the information they already had. Five more minutes were given for this preparation, and they were told that they could write down what they were going 
to present to the other groups. It was expected that they would create a full story based on the information they had so far.

The fourth and last pre-reading task was Reporting. In this moment, the selected student in each group reported to the other groups the hypotheses and/or stories created and discussed with their peers. Other group members could also join the discussion to support their views. It was expected that the whole group would reach a consensus about the possible content of the text or the most suitable story.

\subsubsection{Glossary}

Text B was presented followed by a glossary containing twenty words that were less frequent in the text, according to the Corpus of Contemporary American English (COCA). The lists presented in the texts can be seen below in Table 1 . This procedure was adopted to have a criterion to select the words to be suitable for having their translation explicitly stated on the glossary.

This text was presented without images. All content words from the text were checked on COCA one by one. The twenty words that, according to COCA, had a low frequency were chosen to be part of the glossary (Table 1 below).

TABLE 1 - List of words for the glossary on the narrative text B

\begin{tabular}{llll}
\hline \multicolumn{1}{c}{ Word from the text } & \multicolumn{1}{c}{ Translation } & \multicolumn{1}{c}{ Word from the text } & \multicolumn{1}{c}{ Translation } \\
\hline 1. Arrive & Chegar & 11. Neighbour & Vizinho \\
2. Awful & Horrivel & 12. Noisy & Barulhento \\
3. Bark & Latir & 13. Owners & Donos \\
4. Clean & Limpo & 14. Shouted & Gritou \\
5. Dirty & Sujo & 15. Suppose & Supor \\
6. Easy & Fácil & 16. Staff & Funcionários \\
7. Gave up & Desistir & 17. Trouble & Encrenca \\
8. Get rid & Se livrar & 18.Unwelcomed & Não é bem-vindo \\
9. Last & Ultimo & 19. Way & Jeito \\
10. Lunch & Almoço & 20. Woke up & Acordou \\
\hline
\end{tabular}

Source: Prepared by the authors.

It is worth highlighting that the text with the glossary was used as the control condition, instead of 'nothing before reading' as control, in order to ensure that participants at least could clarify the meaning of less frequent words, in case they needed to. Participants had the glossary available at the end of the text, to follow the usual procedure in textbooks, and, for organization matters, the words were displayed in alphabetical order. No further instructions were given, and they were free to check the meanings available in Portuguese in case they wanted to.

\subsubsection{Reading comprehension test}

According to Pearson and Johnson (1974, p. 154), questions are "a vital part of any discussion activity". Besides, they are also an effective instrument of data collection for research. In the present study, two types of reading comprehension questions based on the taxonomy proposed by Pearson and Johnson (1974) were used: textually explicit and textually implicit questions.

Textually explicit questions do not require much cognitive engagement from the participants since answers can be found on the surface of the text. 
On the other hand, textually implicit questions require much more cognitive engagement from participants since answers will not easily be found in the text, and readers will have to build a situational model ${ }^{6}$ in order to answer them appropriately.

Each text used in the present study was followed by a Reading Comprehension Test (RCT). Each comprehension test had the total amount of six questions organized in the following way: three textually explicit and three textually implicit questions. The questions were organized in this way so that participants would feel motivated to answer from the beginning of the test. More difficult questions in the beginning could make them less motivated to answer the RCT. Furthermore, the question type chosen was open-ended questions. This way, participants would be able to express themselves in the way they would feel comfortable, avoiding that their responses were influenced by possible clues provided in objective tests such as multiple choice and true or false items.

Participants received the comprehension test right after finishing reading each text, and the texts were kept with them, so that they could consult as many times as they needed during the amount of time given. This procedure was adopted since this study was intended to measure comprehension, not participants' memory.

It is important to mention that the RCT is not part of the task cycle, but it is an instrument to access offline comprehension, being the dependent variable of this study. It is also important to highlight that the questions were formulated and answered in Portuguese. This decision was taken for two reasons: one is that we wanted to check text comprehension and not production, and the other was to avoid that participants would copy and paste information directly from the text, also requiring more attention in relation to their answers.

\subsubsection{Procedures for data collection and analysis}

After completing the ethical requirements with the school, participants, and guardians, the data was collected as follows: in the treatment condition, participants were exposed to the prereading tasks, as explained in subsection 2.2.3, read the narrative text, and then took the RCT. In the control condition, participants read the narrative text followed by a glossary, and after reading it, they took the RCT.

As already mentioned, the study followed a within-subject design. In this type of investigation, the same participant is exposed to all conditions: treatment and control During data analysis, the answers in the RCTs were read one by one attributing 1 to fully correct answers; 0.5 to partially correct answers; and o to incorrect answers. After that, the raw values were coded into percentages in order to make results understandable and comparable. Due to the few number of participants, statistical analysis could not be carried out, since too few tokens may not be enough for statistical significance. It is worth to mention that the point of cut considered in these tests was $70 \%$, meaning that, whenever results were equal or above this percentage, they were considered positive.

\section{Results and discussion}

This section aims to present the results obtained during the treatment and control conditions in this study, as well as to discuss them in the light of the literature. Table 2, presented below, displays the percentage of the scores in both treatment and control conditions, obtained by each participant in the Reading Comprehension Test (RCT), done after reading each narrative text. The mean, maximum, and minimum are presented at the bottom of the table following a general discussion of the results presented and the description of the data.

\footnotetext{
6 According to this model, proposed by Kintsch and van Dijk (1978), while the reader conveys textual information, they undergo a series of mental operations that happen to summarize and integrate pieces of information in propositions and construct a mental representation of the text. With their inferences constructed, integrating their background knowledge, beliefs, and textual input, the reader has his/her situation model. The situation model is like our fingerprint, each of us will have a different one, even if we read the same text.
} 
TABLE 2 - Results from the Reading Comprehension Test in both treatment and control conditions

\begin{tabular}{|c|c|c|}
\hline \multirow[t]{2}{*}{ Participant } & \multicolumn{2}{|c|}{ Narrative Texts } \\
\hline & Treatment & Control \\
\hline$P_{1}$ & $83.34 \%$ & $58,34 \%$ \\
\hline P2 & $83,34 \%$ & $44,34 \%$ \\
\hline P3 & $50 \%$ & $25 \%$ \\
\hline P4 & $100 \%$ & $88,84 \%$ \\
\hline P5 & $100 \%$ & $66,67 \%$ \\
\hline P6 & $83.34 \%$ & $25 \%$ \\
\hline P7 & $91,67 \%$ & ०\% \\
\hline P8 & $33.34 \%$ & $55,50 \%$ \\
\hline P9 & $50 \%$ & $72,17 \%$ \\
\hline Mean & $75 \%$ & $48,43 \%$ \\
\hline Minimum & $33.34 \%$ & ०\% \\
\hline Maximum & $100 \%$ & $88,84 \%$ \\
\hline
\end{tabular}

Source: Prepared by the authors.

By analyzing the general picture of the results presented in the table above, it is possible to observe that the results from the treatment session are higher when compared to the control session. The data shows that there was a positive effect concerning the pre-reading tasks since most participants had a positive performance on the RCT. This result was expected since previous studies in the area in relation to pre-reading activities have already shown that pre-reading procedures foster reading comprehension (TIERNEY; CUNNINGHAM, 1980; LANGER, 1980; TAGLIEBER, 1985; TOMITCH, 1991; CARRELL, 2006; ALEMI; EBALDI, 2010; BILOKCUOGLU, 2011, to mention some authors). Thus, this result shows that the pre-reading tasks, as proposed by this present study, are also beneficial to reading comprehension when compared to reading a text with a glossary. Nonetheless, in general, results are not positive in the control condition, as expected. Since text B did not receive any kind of treatment before they read it, it was expected that the participants would not perform well in this test. Previous research shows that readers, especially when reading L2 texts, need some kind of pre-reading procedure before they approach a text, which might be necessary for enabling the reader to activate prior relevant knowledge and construct meaning from the text being read (AEBERSOLD; FIELD, 1997).

Based on Table 2 presented above, it can be observed that $\mathrm{P}_{1}, \mathrm{P}_{2}, \mathrm{P}_{3}, \mathrm{P}_{4}, \mathrm{P}_{5}, \mathrm{P}_{6}$, and $\mathrm{P}_{7}$ obtained higher scores in the RCT after reading the narrative text in the treatment session. This result represents $77,78 \%$ of the sample, which showed an increase in reading comprehension when compared to the control condition. In addition, P8 and P9 scored better in the control session, representing $22,22 \%$ of the sample. However, $\mathrm{P} 1$, P2, P4, P5, P6, and P7 obtained scores above $70 \%$ in the treatment condition, indicating a positive effect of the pre-reading tasks on participants' reading comprehension.

The mean in the treatment session was $75 \%$, which was higher than the $48,43 \%$ obtained by participants in the control session. The maximum score obtained by a participant in the treatment was $100 \%$ scored by $\mathrm{P}_{4}$ and $\mathrm{P}_{5}$, still better when compared with the control session that was $88,84 \%$ obtained by P4. Also, the minimum score obtained by a participant in the treatment condition was $33.34 \%$ by P8, which was better than the $0 \%$ obtained by P7 in the control session.

Even though two participants scored better in the control condition, based on the comparison between treatment and control, it can be noticed that, in general, the comprehension of the narrative text, after participants undertook the pre-reading tasks was better in the treatment situation. This result shows that developing prereading tasks prior to reading a narrative text can foment textual comprehension.

Graph 1 below illustrates participants' individual performance compared in both conditions, treatment and control. 


\section{Graph 1 - Individual performance in the RCT in both treatment and control conditions}

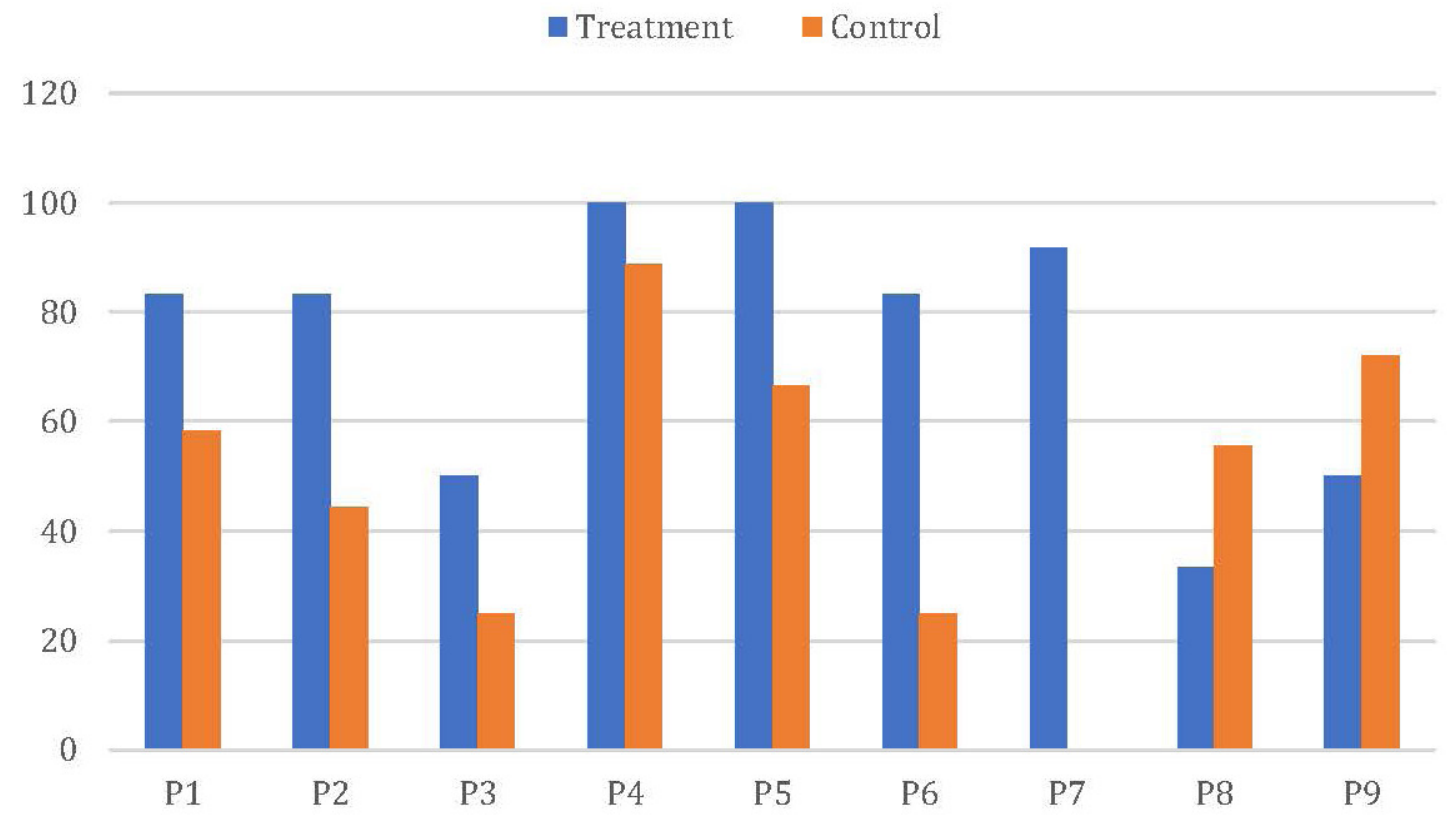

Source: Prepared by the authors.

What we are able to observe from the results above is that, although participants $\mathrm{P} 8$ and $\mathrm{Pg}$ obtained lower scores when compared to the rest of the sample in the treatment session, there was a tendency that the pre-reading procedures adopted before participants read the narrative text, in general, had a positive effect on reading comprehension. Except for P8 and $P 9$, all participants obtained higher scores in the treatment condition.

Considering this discussion and the results displayed, the pre-reading tasks designed with the support of the Task-Based Language Teaching (TBLT) literature brought by Willis and Willis (2011) and adapted to the purpose of this research, in a sense, seemed to have helped readers to build background knowledge and to relate this knowledge to the content of the text. Furthermore, the prereading tasks might have helped to assist readers in making appropriate inferences concerning the content of the text, helping them to answer the proposed test. Additionally, since narratives require the reader to reach global coherence, then the prereading tasks might have also helped participants in this regard, since the procedures adopted prior to reading, helped readers in holistically contextualizing the textual topic.
As already mentioned, the advantages of processing narrative texts are that they follow a chronological sequence of episodes since our everyday life is organized in a similar manner (GRABE, 2009). In this sense, the aforementioned result for the narrative text in the treatment condition also endorses the literature on reading which points that this textual type is easier to be processed by the reader due to the familiarity with the story structure. However, the results obtained in the control condition signal that it is not always the case that readers will succeed in reading narrative texts and that they may need some help, which, in this study, came in the form of pre-reading tasks. As mentioned elsewhere in this text, Benssoussan (1990, p. 49) claims that this textual type requires readers to have knowledge about cultural aspects of the foreign language since narrative texts are full of "cultural-specific materials". In this regard, according to Aebersold and Field (1997), once the reader is introduced to the textual topic in advance, as developed in the treatment condition of this study, cultural awareness may be provided, enhancing comprehension and retention of textual information.

It is common sense in the area of reading that motivation to read and a purpose for reading are key issues to be considered in the L2 classroom 
(e.g. DAVIES, 1995; AEBERSOLD; FIELD, 1997) In this sense, pre-reading tasks have a strong potential to motivate students to read the text, besides giving them an explicit purpose, which is to check the predictions they made during the pre-reading, against the actual text.

Bensoussan (1990) points out that the comprehension of a narrative text is more bounded to global coherence. In this sense, the reader needs a holistic view of the content of the text to make sense of the input information. Thus, the results shown in Table 2 and Graph 1 seem to endorse the idea that the narrative texts used in this research could have required from the participants to establish a strong global coherence of the text and that most of them were not able to achieve in the control condition, that is, without the aid of the pre-reading tasks. A possibility is that without a framework to read the text and appropriate prior knowledge, given in the pre-reading task condition, they were not able to make the appropriate inferences that this textual type requires, and neither could they have a broader view of the topic or content of the text.

In addition, participants might have failed to activate previous knowledge concerning the topic of the text, based solely on having lexical items translated at the bottom of the page in a glossary. Thus, as expected, a glossary seems to have little or no effect to guide participants in reaching a better comprehension of the text, as observed by the results in this study.

\section{Final remarks}

The rationale for this study was nurtured by theoretical support of previous research developed by Taglieber (1985) and Tomitch (1988) in which the authors presented the advantages of reading texts after participants being exposed to pre-reading activities as a way to foster reading comprehension. The second motivation was previous investigations developed by Caldart (2012) and Roscioli (2017) that confronted narrative and expository texts prepared with pre-reading activities and how these two text types would be processed in L2, even though the focus of the present study laid in the narrative text type. The third and final work was Willis and Willis' (2011) approach which proposed the prediction tasks with the support of the Task-Based Language Teaching (TBLT), presented and discussed in this investigation as pre-reading tasks.

Based on the aforementioned literature, the main objective of this study was to investigate if reading comprehension would be affected by the implementation of the proposed prereading tasks. The results of this investigation have shown that pre-reading tasks foster reading comprehension, in the context in which this study was carried out. This result provides empirical support for Willis and Willis (2011), in which the authors claimed that their proposed prediction tasks would work for narratives. To conclude the discussion brought so far, the research question is retaken, accounting for the results presented:

What are the effects of pre-reading tasks (treatment condition), as compared to a glossary (control condition), on the reading comprehension of narrative EFL texts, as measured by comprehension questions?

In the present study, when the narrative text was preceded by the pre-reading tasks designed by Willis and Willis (2011) and adapted to the purpose of this research, there were positive outcomes, that is, in general, readers obtained higher scores on the Reading Comprehension Test, when the text was preceded by pre-reading tasks than when accompanied by a glossary. These results endorse Willis and Willis (2011) in which the authors claim that pre-reading tasks work well for narrative texts. In the context of this investigation, the prereading tasks helped readers to build background knowledge and activate previous schemata during the proposed tasks. As a whole, the participants' reading performance increased in the treatment condition showing a positive effect of the prereading tasks when preceding a narrative text. Differently, the glossary at the end of the text was not enough to help readers to understand the narrative text, not enabling the reader to make the necessary inferences when reading and neither to achieve comprehension. 
We would like to acknowledge the small number of participants as a limitation in the study and we consider that the present results are still inconclusive and in need of additional investigations to verify if there would be differences in comprehension once a text is read with and without pre-reading tasks. However, we believe that the present study may inform future investigations, especially in relation to two aspects: the use of pre-reading tasks following the TBLT approach and their use in the context of public high school contexts.

We also believe that the findings here presented have pedagogical implications to the L2 classroom. Catching students' attention in a classroom is not always a simple task, especially in L2 contexts. This task becomes even harder when an English teacher proposes a reading task. Most of the time, students are not motivated to read due to proficiency and linguistic limitations. As this study has discussed and presented evidence for, this motivation might be raised by the proposed pre-reading tasks, challenging students to make predictions about the texts, therefore, fomenting their curiosity. Even though this research provides empirical evidence for only one text type, adaptations can be made according to teachers' purpose. Most importantly, this preparation to read fosters reading comprehension, enabling readers to better read a passage in $\mathrm{L} 2$.

In addition, this study provides a discussion of an alternative to deal with texts inside a classroom. In that regard, this investigation goes in line with the Orientações Educacionais Complementares aos Parâmetros Curriculares Nacionais do Ensino Médio $(\mathrm{PCN}+$ ) (2002), a Brazilian regulatory document of high school education, which states that the focus of learning should be on the communicative functions, giving prior attention to reading and the comprehension of oral and written texts, embracing different contexts of textual use. In a sense, this is embraced in this study by the use of the pre-reading and reading tasks, as contextualized activities.

\section{References}

AEBERSOLD, J. A.; FIELD, M. L. From Reader to Reading Teacher. Cambridge: Cambridge University Press, 1997.

ALEMI, M.; EBADI, S. The Effects of Pre-reading Activities on ESP Reading Comprehension. Journal of Language Teaching and Research, [s. l.], v. 1, n. 5, 2010. Available at: http://WwW.academypublication.com/issues/past/ jLtr/vol01/05/04.pdf. Accessed on: Jan 5 2020. https:// doi.org/10.4304/jltr.1.5.569-577.

BAILER, C. Working Memory Capacity and Attention to Form and Meaning in EFL Reading. 2011. 102 f. Dissertação (Mestrado) - Universidade Federal de Santa Catarina, Florianópolis, 2011. Available at: https://repositorio.ufsc.br/xmlui/handle/123456789/95008. Accessed on: Jan 52020

BENSOUSSAN, M. EFL reading as seen through translation and discourse analysis: Narrative vs. expository texts. English for Specific Purposes, [s. l.], v. 9, n. 1, p. 49-66, 1990. Available at: https://repositorio.ufsc.br/ xmlui/handle/123456789/95008. Accessed on: Jan 5 2020. https://doi.org/10.1016/0889-4906(90)g0028-B.

BILOKCUOGLU, L. H. The Effects of Pre-Reading Activities in Efl Classes on Students' Reading Comprehension. EUL Journal of Social Sciences, [s. L.], v. 4531, p. 79-97, 2011.

CALDART, D. The Effect of Genre Expectation on EFL Brazilian Student's Inference Generation and Reading Comprehension. 2012. 156fls. Dissertação (Mestrado) - Universidade Federal de Santa Catarina, Florianópolis, 2012.

CARRELL, P. L. Schema Theory and ESL Reading: Classroom Implications and Applications. The Modern Language Journal, [s. l.], v. 68, n. 4, p. 332, 2006. https:// doi.org/10.1111/j.1540-4781.1984.tb02509.X.

CARRELL, P. L.; DEVINE, J.; ESKEY, D. E. Interactive Approaches to Second Language Reading. Cambridge: Cambridge University Press, 1998.

DAVIES, F. Introducing Reading. London: Penguin English, 1995.

DUBRAVAC, S.; DALLE, M. Reader question formation as a tool for measuring comprehension: narrative and expository textual inferences in a second language. Journal of Research in Reading, [s. l.], v. 25, n. 2, p. 217231, 2002. Available at: http://web.a.ebscohost.com/ ehost $/$ detail/detail? vid=5\&sid=3fc1aeoo-da40 $-4 c 66-8 \mathrm{f}-$ 53-cc54ab02de81\%40sessionmgr4010\&bdata = JkF1dGhUeXBLPWLWLHVybCX1aWQmbGFuZz1rbyZzaXRLPWVob3NoLWxpdmU\%3D\#AN=EJ646907\&db=eric. Accessed on: Jan 52020.

ELLIS, R. The Methodology of Task-Based Teaching. Oxford: Oxford University Press, 2003.

ELLIS, R. Task-based language teaching: Sorting out the misunderstandings. International Journal of Applied Linguistics, [s. l.], v. 19, n. 3, p. 221-246, 2009. https://doi. org/10.1111/j.1473-4192.2009.00231.X.

FREEDLE, R; HALE, G.. Acquisition of new comprehension schemata for expository prose by transfer of a narrative schema. In: FREEDLE, R. O. (ed.). New directions in discourse processing. Norwood: Ablex. 1979. p. 121-135. 
GAGNÉ, E. D.; YEKOVICH, C. W:; YEKOVICH, F. R. (ed.). The cognitive psychology of school learning. New York, USA: Harper Collins College Publishers, 1993. p. 267-312.

GOODMAN, K. S. Reading: A Psycholinguistic Guessing Game. Journal of the Reading Specialist, [s. l.], p. 126-135, 1967. https://doi.org/10.1080/19388076709556976.

GOUGH, Philip B. One Second of Reading. The Journal for Research on the Visual Media of Language Expression, [s. l.], v. VI, n. 4, p. 291-320, 1972.

GRABE, W. Reading in a Second Language: Moving from Theory to Practice. 1st ed. New York: Cambridge University Press, 2009.

GRAESSER, A. C. Prose comprehension beyond the word. New York: Springer-Verlag. 1981. https://doi. org/10.1007/978-1-4612-5880-3.

GRAESSER, A.; RIHA, J. R. An application of multiple regression techniques to sentence reading times. In: KIERAS, D.; JUST, M. (ed.). New methods in comprehension research. Hillsdale: Erlbaum. 1984. p. 183-218. https://doi.org/10.4324/9780429505379-9.

KINTSCH, W:; VAN DIJK, T. A. Toward a model of text comprehension and production. Psychological Review, [s. l.], v. 85, n. 5. p. 363-394, 1978. https://doi.org/10.1037/ $\underline{0033-295 \times .85 .5 .363 .}$

LANGER, J. A. From Theory to Practice: A Pre-Reading Plan. [S. l: s. n.], 1980.

LONG, D. L; JOHNS, C. L.; MORRIS, P. E. Comprehension ability in mature readers. In: TRAXLER, M. J.; GERNSBACHER, M. A. (ed.). Handbook of psycholinguistics. 2nd ed. Amsterdam: Elsevier, 2006. p. 801-834.

MINISTÉRIO DA EDUCAÇÃO (MEC). PCN+Ensino Médio: orientações educacionais complementares aos parâmetros curriculares nacionais: linguagens, códigos e suas tecnologias. Brasilia: Ministério da Educação, 2002.

NUNAN. Task-based language teaching. Cambridge: Cambridge University Press, 2004

OAKHILL, J. V:; CAIN, K. Profiles of children with specific reading comprehension difficulties. British Journal of Educational Psychology, Leicester, v. 76, n. 4, p. 683696, 2006. https://doi.org/10.1348/000709905X67610.

PEARSON, P. D.; FIELDING, L. Comprehension instruction. In: BARR, M. L.; MOSENTHAL, K. P. B.; PEARSON, P. D. (ed.). Handbook of reading research. New York: Longman, 1991. p. 815-860.

PEARSON, P. D.; JOHNSON, D. D. Questions. In: PEARSON, P. D.; JOHNSON, D. D Teaching Reading Comprehension. New York: Holt, Rinehart and Winston, 1974. p. 154-177.

ROSCIOLI, D. C. The Relationship between Technical High School Brazilian Students' Working Memory Capacity, Pre-Reading Activities, and Inference Generation in Reading Comprehension in L2. 2017. 235 f. Dissertação (Mestrado) Universidade Federal de Santa Catarina, Florianópolis, 2017.

RUMELHART, D. E. Toward an integrated model of reading. In: DOMINIC, S. (ed.). Attention and Performance IV. Hillsdale: Lawrence Erlbaum, 1977. p. 573-603.
SPIRO, R. J.; TAYLOR, B. M. On investigating children's transition from narrative to expository discourse: The multidimensional nature of psychological text classification. In: TIERNEY, R. J.; ANDERS, P. L.; MITCHELL, J. N (ed.). Understanding readers' understanding. Hillsdale: Erlbaum. 1987. p. 77-93.

STEIN, N. L.; GLENN, C. G. An analysis of story comprehension in elementary school children. In: FREEDLE, R. O. (ed.). Theoretical issues in reading comprehension: Perspectives from cognitive psychology, linguistics, artificial intelligence, and education. Hillsdale: Erlbaum, 1976. p. 245-278.

TAGLIEBER, L. K. The effectiveness of three prereading activities on English as a foreing language students' comprehension of English texts. Unpublished dissertation P. H. D. -University of lowa, lowa City, 1985

TIERNEY, R. J.; CUNNINGHAM, J. W. Research on Teaching Reading Comprehension. Washington: National Institute of Education (DHEW) , 1980.

TOMITCH, L. M. B. Pesquisas sobre os aspectos cognitivos da leitura: 40 anos de PPGI. In: FUNCK, S. B. História e memória: 40 anos do PPGI da UFSC. Florianópolis: UFSC-CCE-PPGI, 2011. p. 51-62.

TOMITCH, L. M. B. Schema Activation and Text Comprehension. 1988. 75 f. Dissertação (Mestrado) - Universidade Federal de Santa Catarina, Florianópolis, 1988. Disponivel em: https://repositorio.ufsc.br/xmlui/ bitstream/handle/123456789/75496/83643.pdf?sequence $=1 \&$ is Allowed $=y$ Accessed on: Jan 52020 .

TOMITCH, Lêda Maria Braga. Schema Activation and Text Comprehension. Fragmentos, [s. l.], v. 3, n. 2, p. 29-43, 1991. Available at: https://repositorio.ufsc.br/xmlui/ handle/123456789/75496. Accessed on: Jan 52020.

TOMITCH, L. M. B. Aquisição de leitura em língua inglesa. In: LIMA, D. C. (ed.). Ensino e aprendizagem de lingua inglesa: conversas com especialistas. São Paulo: Parábola Editorial, 2009. p. 191-201.

WILLIS, D.; WILLIS, J. Doing Task-Based Teaching. 10th ed. Oxford: Oxford University Press, 2011.

WILLIS, J. Criteria for identifying tasks for TBT. 2007. Available at: https://Www.teachingenglish.org.uk/article/ criteria-identifying-tasks-tbl. Accessed on: Jan 52020.

XAVIER, R. P. Metodologia do Ensino de Inglês. 1. ed. Florianópolis: LLE/CCE/UFSC, 2012.

ZWAAN, R. A.; RAPP, D. N. Discourse comprehension. In: GERNSBACHER, M. A.; TRAXLER, M. J. (ed.). Handbook of psychoinguiscs. San Diego: Elsevier, 2006. p. 725-764. DOI: 10.1016/B978-012369374-7/50019-5.

\section{Dionatan Bastos Cardozo}

Dionatan Bastos Cardozo has an M.A. in English Language and Literature from Programa de Pós-Graduação em Inglês: Estudos Linguísticos e Literários, from Universidade Federal de Santa Catarina, and an undergraduate degree in English and Portuguese from Universidade Federal do Rio Grande- RS. 


\section{Lêda Maria Braga Tomitch}

Lêda M. B. Tomitch is a full professor at the Department of Foreign Languages and Literature from Universidade Federal de Santa Catarina. She was a visiting scholar at the Center for Cognitive Brain Imaging at Carnegie Mellon University- USA (1999-2000) and at the Research Centre for Cognitive Neuroscience at the University of Auckland- NZ (2018).

\section{Mailing address:}

Dionatan Bastos Cardozo

Universidade Federal de Santa Catarina

Rua 428, Roberto Sampaio Gonzaga, 274

Trindade, 88040-380

Florianópolis, SC, Brasil 